\title{
Erythrobacter gangjinensis sp. nov., a marine bacterium isolated from seawater
}

Correspondence

Jae Sung Jung

jjung@sunchon.ac.kr

\author{
Young Sun Lee, ${ }^{1}$ Dong-Heon Lee, ${ }^{2}$ Hyung-Yeel Kahng, ${ }^{2}$ Eun Mi Kim ${ }^{3}$ \\ and Jae Sung Jung ${ }^{1}$
}

\author{
${ }^{1}$ Department of Biology, Sunchon National University, Suncheon 540-742, Republic of Korea \\ ${ }^{2}$ Department of Environmental Education, Sunchon National University, Suncheon 540-742, \\ Republic of Korea \\ ${ }^{3}$ Department of Dental Hygiene, Gwangju Health College, Gwangju 506-701, Republic of Korea
}

A novel Gram-negative, aerobic, orange-pigmented bacterial strain, designated $\mathrm{K} 7-2^{\top}$, was isolated from seawater of Gangjin Bay, Korea, and subjected to a polyphasic taxonomic study. Strain K7-2 ${ }^{\top}$ contained ubiquinone-10 (Q-10) as the predominant respiratory lipoquinone and did not produce bacteriochlorophyll a. Major fatty acids were $\mathrm{C}_{18: 1} \omega 7 c(51.4 \%)$, iso- $\mathrm{C}_{15: 0}$ 2-OH and/or $\mathrm{C}_{16: 1} \omega 7 c(15.0 \%)$ and $\mathrm{C}_{17: 1} \omega 6 c$ (8.8\%). Major polar lipids were phosphatidylethanolamine and phosphatidylcholine. The DNA G+C content was $61.6 \mathrm{~mol} \%$. Phylogenetic analyses based on $16 \mathrm{~S}$ rRNA gene sequences revealed that strain $\mathrm{K} 7-2^{\top}$ formed a distinct phylogenetic lineage within the cluster comprising Erythrobacter strains. Similarities between the 16S rRNA gene sequences of strain $\mathrm{K} 7-2^{\top}$ and the type strains of Erythrobacter species ranged from $95.0 \%$ (Erythrobacter litoralis DSM 8509 ${ }^{\top}$ ) to $96.8 \%$ (Erythrobacter citreus $\left.\mathrm{RE} 35 \mathrm{~F} / 1^{\top}\right)$. On the basis of polyphasic taxonomic data, strain $\mathrm{K} 7-2^{\top}\left(=\mathrm{KCTC} 22330^{\top}=\mathrm{JCM}\right.$ $15420^{\top}$ ) is classified in a novel species within the genus Erythrobacter, for which the name Erythrobacter gangjinensis sp. nov. is proposed.
The genus Erythrobacter, proposed by Shiba \& Simidu (1982), belongs to the $\alpha$-subclass of the Proteobacteria and the family Erythrobacteraceae. This family contains the genera Altererythrobacter (Kwon et al., 2007), Erythrobacter, Porphyrobacter and Erythromicrobium (Lee et al., 2005), which previously belonged to the family Sphingomonadaceae. At the time of writing, the genus Erythrobacter contains eight species: E. longus (Shiba \& Simidu, 1982), E. litoralis (Yurkov et al., 1994), E. citreus (Denner et al., 2002), E. flavus (Yoon et al., 2003), E. aquimaris (Yoon et al., 2004), E. vulgaris (Ivanova et al., 2005), E. seohaensis and E. gaetbuli (Yoon et al., 2005). During bacteriological testing of seawater from shellfish culture, to determine the safety of shellfish for human consumption, a novel Gram-negative marine bacterium producing orange pigments, designated strain $\mathrm{K} 7-2^{\mathrm{T}}$, was isolated. On the basis of polyphasic analysis of phenotypic and phylogenetic data, we propose that strain $\mathrm{K} 7-2^{\mathrm{T}}$ should be assigned to a novel species of the genus Erythrobacter.

\footnotetext{
Abbreviation: BChl a, bacteriochlorophyll a.

The GenBank/EMBL/DDBJ accession number for the 16S rRNA gene sequence of strain $\mathrm{K} 7-2^{\top}$ is EU428782.

A scanning electron micrograph of cells of strain $\mathrm{K} 7-2^{\top}$ is available with the online version of this paper.
}

Strain $\mathrm{K} 7-2^{\mathrm{T}}$ was isolated from seawater collected from Gangjin Bay $\left(34^{\circ} 27^{\prime} \mathrm{N} 126^{\circ} 47^{\prime} \mathrm{E}\right)$, Korea, by using a standard dilution-plating technique on marine agar 2216 (MA; Difco) at $28{ }^{\circ} \mathrm{C}$ for 5 days. Subcultivation was routinely performed on $\mathrm{MA}$ at $30{ }^{\circ} \mathrm{C}$ for 3 days under aerobic conditions and the strain was stored at $-80{ }^{\circ} \mathrm{C}$ in marine broth (MB; Difco) supplemented with $20 \%$ (v/v) glycerol.

Bacterial genomic DNA was extracted using a commercial genomic DNA extraction kit (Bioneer). The 16S rRNA gene was amplified by using the universal bacterial primers $27 \mathrm{f}\left(5^{\prime}\right.$-AGAGTTTGATCCTGGCTCAG-3') and 1525r (5' AAAGGAGGTGATCCAGCC-3') (Lane, 1991) and the purified PCR product was sequenced. The almost-complete $16 \mathrm{~S}$ rRNA gene sequence of strain $\mathrm{K} 7-2^{\mathrm{T}}$ (1435 nt) was aligned manually with those of type strains of Erythrobacter species obtained from GenBank. Secondary-structural information implemented in the jPHYDIT program (Jeon et al., 2005) was used for accurate alignment. Phylogenetic trees were inferred by using three tree-making algorithms, neighbour joining (Saitou \& Nei, 1987), maximum likelihood (Felsenstein, 1981) and maximum parsimony (Fitch, 1971), in the jPHYDIT program and PAUP 4.0 (Swofford, 1998). Evolutionary distance matrices were generated according to Jukes \& Cantor (1969). The tree topologies obtained were evaluated by bootstrap analyses 
(Felsenstein, 1981) of the neighbour-joining method based on 1000 replications.

The initial similarity analyses of 16S rRNA gene sequences indicated that strain $\mathrm{K} 7-2^{\mathrm{T}}$ was closely related to the genus Erythrobacter. Similarities between the $16 \mathrm{~S}$ rRNA gene sequence of strain $\mathrm{K} 7-2^{\mathrm{T}}$ and those of the type strains of recognized Erythrobacter species ranged from 96.8 to $95.0 \%$. The closest relative of strain $\mathrm{K} 7-2^{\mathrm{T}}$ was E. citreus RE35F $/ 1^{\mathrm{T}}$ (96.8\% 16S rRNA gene sequence similarity), followed by E. seohaensis SW-135 ${ }^{\mathrm{T}}(96.3 \%)$, E. aquimaris SW-110 ${ }^{\mathrm{T}}(96.1 \%)$, E. vulgaris $022-2-10^{\mathrm{T}}(96.0 \%)$, E. gaetbuli SW-161 ${ }^{\mathrm{T}}(95.6 \%)$, E. flavus SW- $46^{\mathrm{T}}(95.5 \%)$, E. longus DSM $6997^{\mathrm{T}}(95.3 \%)$ and E. litoralis DSM $8509^{\mathrm{T}}$ $(95.0 \%)$. Also, strain $\mathrm{K} 7-2^{\mathrm{T}}$ occupied a distinct position in the neighbour-joining tree (Fig. 1).

The phenotypic properties of strain $\mathrm{K} 7-2^{\mathrm{T}}$ were tested using standard procedures. Cell morphology was examined with a scanning electron microscope (S-4800; Hitachi) using cells grown for $18 \mathrm{~h}$ at $30{ }^{\circ} \mathrm{C}$ on $\mathrm{MB}$ (Supplementary Fig. S1, available in IJSEM Online). The optimal temperature and temperature range for growth were tested on MA at $4,10,15,20,25,30,35,37,40,42,45$ and $50{ }^{\circ} \mathrm{C}$. Tolerance to sea salts and growth with $\mathrm{NaCl}$ as the sole salt were determined on ZoBell agar (ZoBell, 1946; 5 g Bacto peptone, $1 \mathrm{~g}$ yeast extract, $0.1 \mathrm{~g}$ ferric citrate, $15 \mathrm{~g}$ Bacto agar, 11 distilled water) containing $0-10 \%(\mathrm{w} / \mathrm{v})$ sea salts (Sigma) and $0-10 \% \mathrm{NaCl}$ at intervals of $1 \%$, respectively. Tolerance to $\mathrm{NaCl}$ was determined in modified ZoBell medium (5 g Bacto peptone, $1 \mathrm{~g}$ Bacto yeast extract, $7 \mathrm{~g}$
$\mathrm{MgCl}_{2} \cdot 6 \mathrm{H}_{2} \mathrm{O}, 3 \mathrm{~g} \mathrm{MgSO}_{4} \cdot 7 \mathrm{H}_{2} \mathrm{O}, 1 \mathrm{~g} \mathrm{CaCl}_{2} \cdot 2 \mathrm{H}_{2} \mathrm{O}, 1 \mathrm{~g}$ $\mathrm{KCl}, 1 \mathrm{l}$ distilled water) supplemented with $0-10 \% \mathrm{NaCl}$ at intervals of $1 \%$. The $\mathrm{pH}$ range for growth was assessed on ZoBell medium containing $2 \%$ sea salts adjusted to $\mathrm{pH} 3.0-11.0$ at intervals of $1 \mathrm{pH}$ unit with $\mathrm{HCl}$ or $\mathrm{NaOH}$ after sterilization. Gliding motility was tested by the hanging-drop method as described by Suzuki et al. (2001). Anaerobic growth was tested on MA in a jar containing the AnaeroPack-Anaero (Mitsubishi Gas Chemical), which works as oxygen absorber and $\mathrm{CO}_{2}$ generator, for up to 10 days. Catalase and oxidase activities were determined using standard methods (Tindall et al., 2007). Enzymic hydrolysis of casein, chitin, starch and Tween 80 was examined on MA amended with $1 \%$ substrates as described by Hansen \& Sørheim (1991). Antibiotic resistance was determined with the discdiffusion method using commercial antibiotic-impregnated discs (BBL Becton Dickinson). Other phenotypic and enzymic characterizations of strain $\mathrm{K} 7-2^{\mathrm{T}}$ were conducted using API 20E, API 20NE and API ZYM kits (bioMérieux). The utilization of different carbon sources was tested with a GN2 MicroPlate (Biolog) according to the manufacturer's instructions. Bacterial suspensions were prepared in artificial seawater or $2 \%$ sea salts. Detailed results of morphological, physiological and biochemical tests are given in the species description and in Table 1.

Analysis of the in vitro pigment-absorption spectrum was performed as described by Yoon et al. (2005). In brief, cells cultivated aerobically in the dark at $30{ }^{\circ} \mathrm{C}$ in MB were washed twice using a $20 \mathrm{mM}$ MOPS buffer ( $\mathrm{pH}$ 7.0) and disrupted

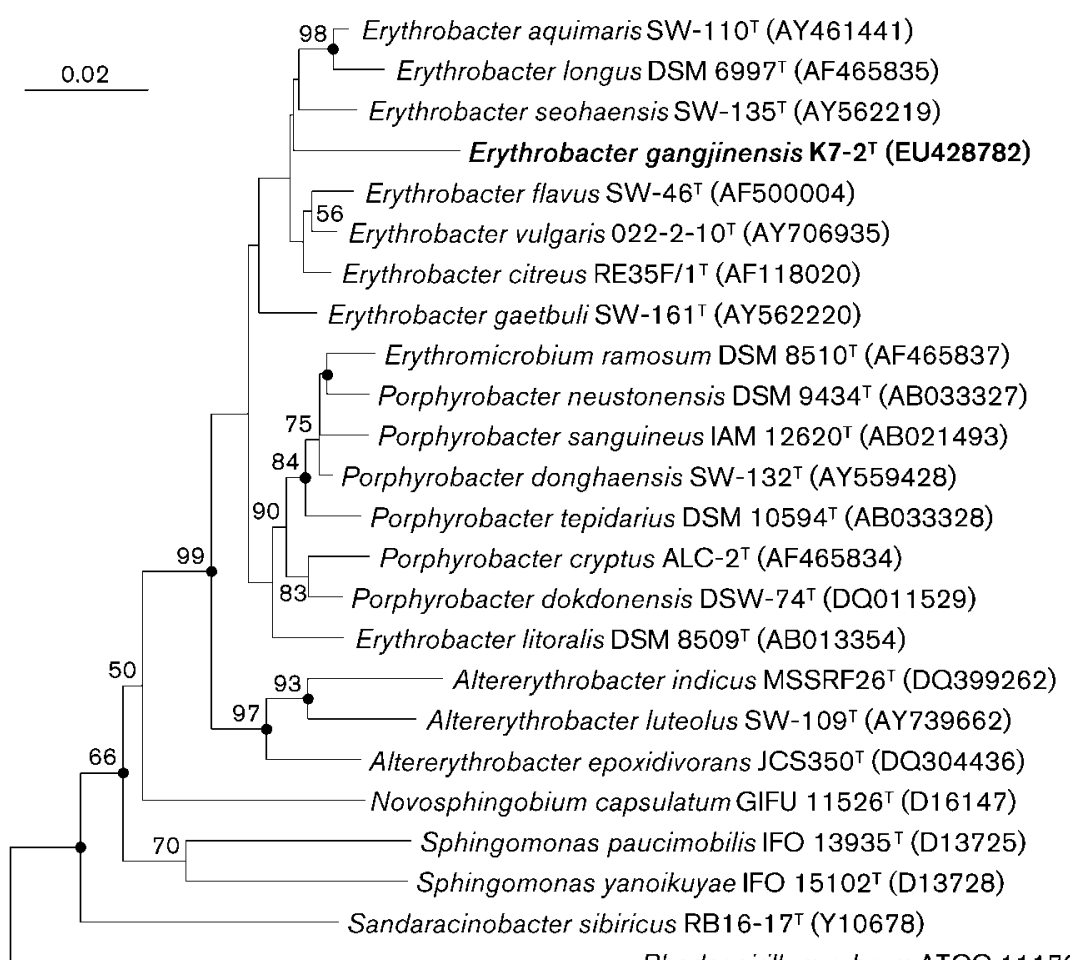

Rhodospirillum rubrum ATCC $11170^{\top}$

\begin{abstract}
Fig. 1. Neighbour-joining tree based on $16 \mathrm{~S}$ rRNA gene sequences showing relationships between strain $\mathrm{K} 7-2^{\top}$ and related strains belonging to the family Sphingomonadaceae. Bootstrap values $(>50 \%)$ based on 1000 replications are given at branch nodes. Filled circles indicate that the corresponding nodes were also recovered in maximum-parsimony and maximum-likelihood trees. Rhodospirillum rubrum ATCC $11170^{\top}$ was used as an outgroup. Bar, 0.02 substitutions per nucleotide position.
\end{abstract}


Table 1. Characteristics that differentiate strain $\mathrm{K} 7-2^{\top}$ from related Erythrobacter strains

Strains: 1, Erythrobacter gangjinensis $\mathrm{K} 7-2^{\mathrm{T}}$; 2. E. flavus $\mathrm{KCCM} 41642^{\mathrm{T}}$; 3, E. seohaensis $\mathrm{KCTC} 12228^{\mathrm{T}}$; 4, E. aquimaris $\mathrm{KCCM} 41818^{\mathrm{T}}$; 5, E. citreus KCTC $12214^{\mathrm{T}}$; 6, E. longus KCCM $12180^{\mathrm{T}}$. All data are from this study. All strains were positive for alkaline phosphatase, esterase (C4), leucine arylamidase, valine arylamidase, trypsin and acid phosphatase activities, hydrolysis of Tween 80 and susceptibility to ( $\mu \mathrm{g}$ per disc) kanamycin (30), chloramphenicol (30), erythromycin (15), vancomycin (30), gentamicin (10), novobiocin (30) and rifampicin (5). All strains were negative for arginine dihydrolase, lysine decarboxylase, ornithine decarboxylase, citrate utilization, $\mathrm{H}_{2} \mathrm{~S}$ production, urease, indole production, fermentation/ oxidation of D-glucose, D-mannitol, inositol, D-sorbitol, L-rhamnose, sucrose, melibiose, amygdalin, L-arabinose, lipase (C14), $\alpha$-galactosidase, $\beta$-glucuronidase, $\beta$-glucosidase, $N$-acetyl- $\beta$-glucosaminidase, $\alpha$-mannosidase and $\alpha$-fucosidase activities, hydrolysis of agar and casein and susceptibility to polymyxin B (300 U) and ( $\mu$ g per disc) streptomycin (10) and nalidixic acid (30).

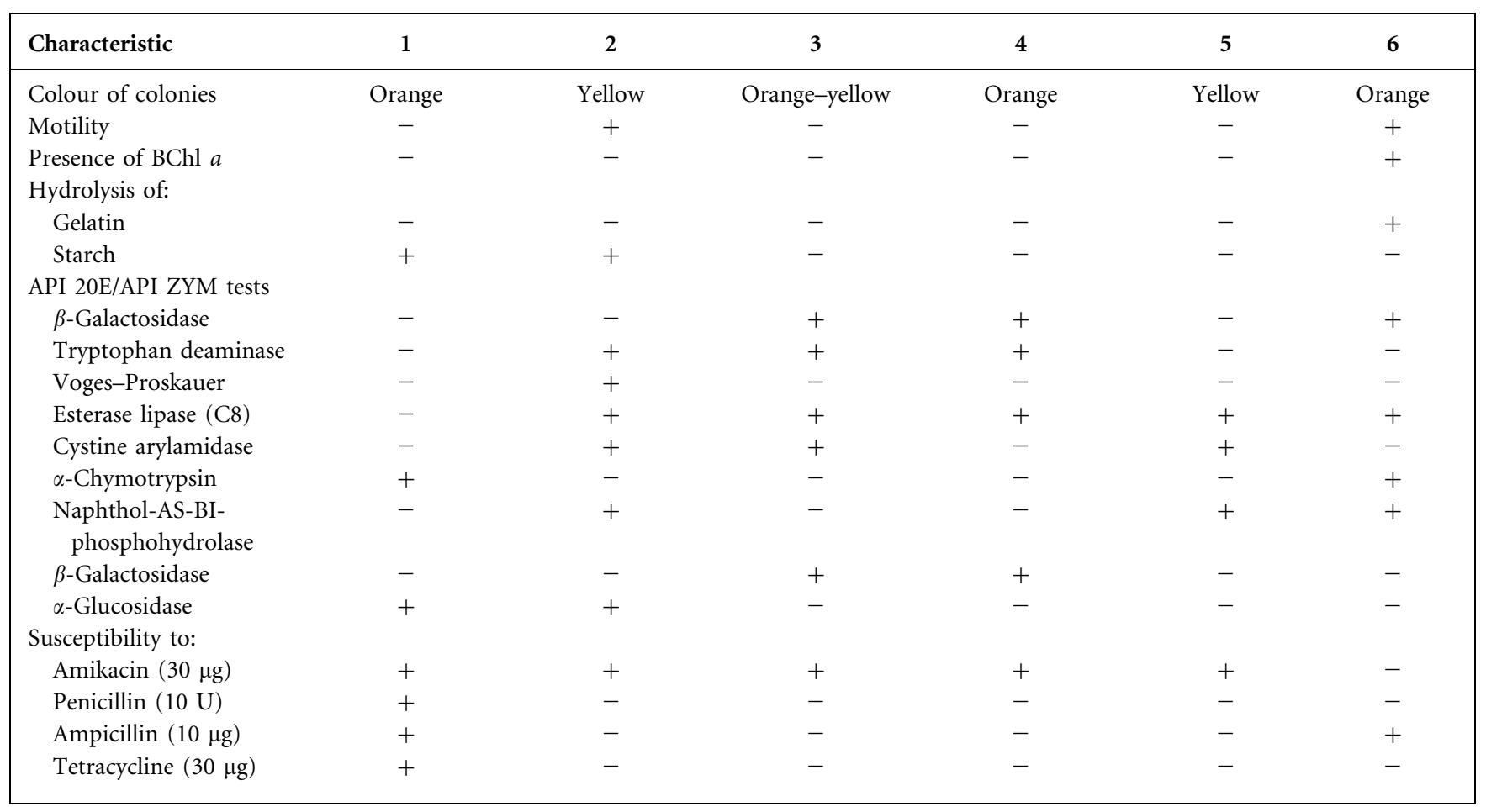

by sonication with a Cole-Parmer ultrasonic homogenizer 4710. After removal of cell debris, the absorption spectrum of the supernatant was examined on a Shimadzu UV-1601 spectrophotometer. Bacteriochlorophyll $a(\mathrm{BChl} a)$ was not detected in vitro in strain $\mathrm{K} 7-2^{\mathrm{T}}$. E. longus $\mathrm{KCCM} 12180^{\mathrm{T}}$ was used as a positive control for spectrum analysis. Although the presence of BChl $a$ was one of the characteristics of the genus Erythrobacter, only the two first-described species, E. longus and E. litoralis, contain this photopigment (Shiba \& Simidu, 1982; Yurkov et al., 1994). Therefore, it has been proposed that this trait be removed from the genus description (Denner et al., 2002). Respiratory lipoquinones were analysed as described elsewhere (Collins \& Jones, 1980; Komagata \& Suzuki, 1987). Ubiquinones were extracted from $200 \mathrm{mg}$ dry cell mass with chloroform and methanol $(2: 1, \mathrm{v} / \mathrm{v})$. After drying in a rotary evaporator, the residue was dissolved in $500 \mu \mathrm{l}$ acetone. The extract was applied to the TLC plate $\left(20 \times 20\right.$, silica gel $60 \mathrm{~F}_{254}$; Merck $)$ and developed using petroleum ether and acetone $(95: 5, \mathrm{v} / \mathrm{v})$. Purified ubiquinones were dissolved in acetone and loaded on a reversed-phase TLC plate $(10 \times 10$, HPTLC silica gel 60 $\mathrm{RP}-18 \mathrm{~F}_{254}$; Merck) and developed with acetone/acetonitrile $(80: 20, \mathrm{v} / \mathrm{v})$. Reference compounds were obtained from
Sigma. The predominant respiratory lipoquinone was ubiquinone-10 (Q-10), which has been found in other Erythrobacter species (Denner et al., 2002; Yoon et al., 2003, 2004, 2005). Polar lipids were extracted according to the procedures described by Minnikin et al. (1984) and separated by two-dimensional TLC using silica gel $60 \mathrm{~F}_{254}$ plates. Individual phospholipids were identified by spraying with appropriate detection reagents and co-migration with authentic standards (Sigma) (Komagata \& Suzuki, 1987). Phosphatidylethanolamine and phosphatidylcholine were identified as the predominant phospholipids.

The total cellular fatty acid compositions of strain $\mathrm{K} 7-2^{\mathrm{T}}$ and related strains were analysed according to the instructions of the Microbial Identification System (MIDI) using cells grown on MA at $30{ }^{\circ} \mathrm{C}$ for 2 days. The cellular fatty acid composition of strain $\mathrm{K} 7-2^{\mathrm{T}}$ is shown in Table 2, together with those of the type strains of Erythrobacter species. Major cellular fatty acids of strain $\mathrm{K} 7-2^{\mathrm{T}}$ were $\mathrm{C}_{18: 1} \omega 7 c(51.4 \%)$, summed feature 3 (consisting of iso- $\mathrm{C}_{15: 0} 2-\mathrm{OH}$ and/or $\left.\mathrm{C}_{16: 1} \omega 7 c ; 15.0 \%\right)$ and $\mathrm{C}_{17: 1} 1 \omega 6 c(8.8 \%)$. The $\mathrm{G}+\mathrm{C}$ content of the DNA was determined by thermal denaturation method (Marmur \& Doty, 1962) using Ultrospec 2100 
Table 2. Cellular fatty acid compositions of strain $K 7-2^{\top}$ and the type strains of related Erythrobacter species

Strains: 1, Erythrobacter gangjinensis $\mathrm{K} 7-2^{\mathrm{T}} ; 2$. E. flavus KCCM $41642^{\mathrm{T}}$; 3, E. seohaensis KCTC $12228^{\mathrm{T}}$; 4, E. aquimaris $\mathrm{KCCM} 41818^{\mathrm{T}}$; 5, E. citreus KCTC $12214^{\mathrm{T}}$; 6, E. longus KCCM $12180^{\mathrm{T}}$. All data are from this study. tr, Trace amount $(<0.5 \%$ of total); - , not detected.

\begin{tabular}{|c|c|c|c|c|c|c|}
\hline Fatty acid (\%) & 1 & 2 & 3 & 4 & 5 & 6 \\
\hline \multicolumn{7}{|l|}{ Saturated straight-chain } \\
\hline $\mathrm{C}_{14: 0}$ & 0.5 & - & 0.5 & 0.8 & - & - \\
\hline $\mathrm{C}_{16: 0}$ & 6.4 & 5.2 & 11.8 & 14.3 & 4.6 & 11.9 \\
\hline $\mathrm{C}_{17: 0}$ & - & 2.4 & $\operatorname{tr}$ & $\operatorname{tr}$ & - & 7.8 \\
\hline $\mathrm{C}_{18: 0}$ & 1.0 & - & 1.2 & - & 1.9 & 1.2 \\
\hline \multicolumn{7}{|l|}{ Unsaturated } \\
\hline $\mathrm{C}_{16: 1} \omega 5 c$ & 0.8 & - & 1.5 & 1.2 & - & - \\
\hline $\mathrm{C}_{16: 1} \omega 11 c$ & - & - & - & - & - & 0.5 \\
\hline $\mathrm{C}_{17: 1} \omega 6 c$ & 8.8 & 5.8 & 7.3 & 7.9 & 13.9 & 3.6 \\
\hline $\mathrm{C}_{17: 1} \omega 8 c$ & - & 8.8 & 1.1 & - & - & 5.1 \\
\hline $\mathrm{C}_{18: 1} \omega 5 c$ & - & - & 1.3 & 0.5 & 1.5 & - \\
\hline $\mathrm{C}_{18: 1} \omega 7 c$ & 51.4 & 56.3 & 38.2 & 42.8 & 45.0 & 52.3 \\
\hline $\mathrm{C}_{18: 1} \omega 9 c$ & - & - & 0.5 & - & - & - \\
\hline 11-Methyl-C $18: 1 \omega 7 c$ & 3.6 & 4.6 & 4.0 & 4.1 & 8.1 & - \\
\hline \multicolumn{7}{|l|}{ Hydroxy } \\
\hline $\mathrm{C}_{14: 0} 2-\mathrm{OH}$ & 5.1 & 1.6 & 11.5 & 8.9 & 3.5 & 6.5 \\
\hline $\mathrm{C}_{15: 0} 2-\mathrm{OH}$ & 1.3 & 6.1 & 2.7 & 1.9 & 2.8 & 9.7 \\
\hline $\mathrm{C}_{16: 0} 2-\mathrm{OH}$ & 4.7 & 1.6 & 2.6 & 1.6 & 5.7 & 1.4 \\
\hline iso- $\mathrm{C}_{16: 0} 3-\mathrm{OH}$ & - & - & 0.9 & - & 1.5 & - \\
\hline $\mathrm{C}_{16: 1} 2-\mathrm{OH}$ & - & - & 0.8 & - & 1.8 & - \\
\hline $\mathrm{C}_{18: 1} 2-\mathrm{OH}$ & 1.5 & - & 0.9 & - & 4.1 & - \\
\hline Summed feature $3^{*}$ & 15.0 & 7.7 & 12.8 & 15.7 & 5.6 & - \\
\hline
\end{tabular}

* Summed features represent two or three fatty acids that cannot be separated by the Microbial Identification System. Summed feature 3 consisted of iso- $\mathrm{C}_{15: 0} 2-\mathrm{OH}$ and/or $\mathrm{C}_{16: 1} \omega 7 c$.

spectrophotometer (Pharmacia Biotech). DNA from Escherichia coli $\mathrm{K}-12$ was used as a control. The DNA $\mathrm{G}+\mathrm{C}$ content of strain $\mathrm{K} 7-2^{\mathrm{T}}$ was $61.6 \mathrm{~mol} \%$.

On the basis of the analysis presented above, strain $\mathrm{K} 7-2^{\mathrm{T}}$ is a member of the genus Erythrobacter and distinguishable from described Erythrobacter species. Therefore, a novel species is proposed, with the name Erythrobacter gangjinensis sp. nov.

\section{Description of Erythrobacter gangjinensis sp. nov.}

Erythrobacter gangiinensis (gang.jin.en'sis. N.L. masc. adj. gangjinensis referring to Gangjin, the name of the bay in Korea from which the type strain was isolated).

Cells are Gram-negative, aerobic rods, approximately $0.3-$ $0.4 \times 0.6-0.8 \mu \mathrm{m}$ in size. Colonies are smooth, circular with entire margin, convex, opaque and orange on MA. After growth on $\mathrm{MA}$ at $30^{\circ} \mathrm{C}$ for 7 days, colonies are 1.0 $1.2 \mathrm{~mm}$ in diameter. No growth occurs with $\mathrm{NaCl}$ as the sole salt. Optimal growth occurs with $2-3 \%(w / v) ~ N a C l$; no growth occurs without $\mathrm{NaCl}$ or with $>5 \% \mathrm{NaCl}$. Growth occurs with 1-7\% (w/v) sea salt. Growth occurs at $15-37{ }^{\circ} \mathrm{C}$ (optimum $30{ }^{\circ} \mathrm{C}$; no growth above $40{ }^{\circ} \mathrm{C}$ ) and $\mathrm{pH}$ 6.0-10.0 (optimum pH 7-8). Bacteriochlorophyll $a$ is not detected. Sensitive to ( $\mu \mathrm{g}$ per disc unless otherwise indicated) ampicillin (10), chloramphenicol (30), erythromycin (15), penicillin (10 U), tetracycline (30), kanamycin (30), amikacin (30), gentamicin (10), vancomycin (30), novobiocin (30) and rifampicin (5), but resistant to polymyxin B (300 U), streptomycin (10) and nalidixic acid (30). Positive for catalase and oxidase activities. Starch and Tween 80 are hydrolysed, but chitin and casein are not. According to API ZYM tests, activities for alkaline phosphatase, esterase (C4), leucine arylamidase, valine arylamidase, trypsin, $\alpha$-chymotrypsin, acid phosphatase and $\alpha$-glucosidase are present, but activities for esterase lipase (C8), lipase (C14), cystine arylamidase, naphtholAS-BI-phosphohydrolase, $\alpha$ - and $\beta$-galactosidase, $\beta$-glucuronidase, $\beta$-glucosidase, $N$-acetyl- $\beta$-glucosaminidase, $\alpha$ mannosidase and $\alpha$-fucosidase are absent. According to API 20NE and API 20E tests, nitrate is not reduced, VogesProskauer test is negative, $\mathrm{H}_{2} \mathrm{~S}$ and indole are not produced and activities for glucose fermentation, aesculin hydrolysis, urease and arginine dihydrolase are absent. With Biolog GN2, utilizes $\alpha$-cyclodextrin, glycogen, Tweens 40 and 80 , turanose, pyruvic acid methyl ester, succinic acid monomethyl ester, $\beta$-hydroxybutyric acid, $\alpha$-ketoglutaric acid, succinic acid, succinamic acid, L-alanine, L-alanyl glycine, L-glutamic acid, glycyl L-glutamic acid and L-proline. The predominant respiratory lipoquinone is Q-10. The major cellular fatty acids of strain $\mathrm{K} 7-2^{\mathrm{T}}$ were $\mathrm{C}_{18: 1} \omega 7 \mathrm{c}$, iso- $\mathrm{C}_{15: 0}$ 2-OH and/or $\mathrm{C}_{16: 1} \omega 7 c$ and $\mathrm{C}_{17: 1} \omega 6 c$. The DNA G+C content of the type strain is $61.6 \mathrm{~mol} \%$.

The type strain, $\mathrm{K} 7-2^{\mathrm{T}}\left(=\mathrm{KCTC} 22330^{\mathrm{T}}=\mathrm{JCM} 15420^{\mathrm{T}}\right)$, was isolated from seawater of Gangjin Bay, Korea.

\section{References}

Collins, M. D. \& Jones, D. (1980). Lipids in the classification and identification of coryneform bacteria containing peptidoglycans based on 2,4-diaminobutyric acid. J Appl Bacteriol 48, 459-470.

Denner, E. B. M., Vybiral, D., Koblížek, M., Kämpfer, P., Busse, H.-J. \& Velimirov, B. (2002). Erythrobacter citreus sp. nov., a yellowpigmented bacterium that lacks bacteriochlorophyll $a$, isolated from the western Mediterranean Sea. Int J Syst Evol Microbiol 52, 16551661.

Felsenstein, J. (1981). Evolutionary trees from DNA sequences: a maximum likelihood approach. J Mol Evol 17, 368-376.

Fitch, W. M. (1971). Toward defining the course of evolution: minimum change for a specific tree topology. Syst Zool 20, 406-416.

Hansen, G. H. \& Sørheim, R. (1991). Improved method for phenotypical characterization of marine bacteria. J Microbiol Methods 13, 231-241.

Ivanova, E. P., Bowman, J. P., Lysenko, A. M., Zhukova, N. V., Gorshkova, N. M., Kuznetsova, T. A., Kalinovskaya, N. I., Shevchenko, L. S. \& Mikhailov, V. V. (2005). Erythrobacter vulgaris sp. nov., a novel organism isolated from the marine invertebrates. Syst Appl Microbiol 28, 123-130. 
Jeon, Y. S., Chung, H., Park, S., Hur, I., Lee, J. H. \& Chun, J. (2005). jPHYDIT: a JAVA-based integrated environment for molecular phylogeny of ribosomal RNA sequences. Bioinformatics 21, 3171-3173.

Jukes, T. H. \& Cantor, C. R. (1969). Evolution of protein molecules. In Mammalian Protein Metabolism, vol. 3, pp. 21-132. Edited by H. N. Munro. New York: Academic Press.

Komagata, K. \& Suzuki, K. (1987). Lipid and cell-wall analysis in bacterial systematics. Methods Microbiol 19, 161-207.

Kwon, K. K., Woo, J.-H., Yang, S.-H., Kang, J.-H., Kang, S. G., Kim, S.-J., Sato, T. \& Kato, C. (2007). Altererythrobacter epoxidivorans gen. nov., sp. nov., an epoxide hydrolase-active, mesophilic marine bacterium isolated from cold-seep sediment, and reclassification of Erythrobacter luteolus Yoon et al. 2005 as Altererythrobacter luteolus comb. nov. Int J Syst Evol Microbiol 57, 2207-2211.

Lane, D. J. (1991). 16S/23S rRNA sequencing. In Nucleic Acid Techniques in Bacterial Systematics, pp. 115-175. Edited by E. Stackebrandt \& M. Goodfellow. Chichester, UK: Wiley.

Lee, K.-B., Liu, C.-T., Kim, H., Aono, T. \& Oyaizu, H. (2005). The hierarchical system of the 'Alphaproteobacteria': description of Hyphomonadaceae fam. nov., Xanthobacteraceae fam. nov. and Erythrobacteraceae fam. nov. Int J Syst Evol Microbiol 55, 1907-1919.

Marmur, J. \& Doty, P. (1962). Determination of the base composition of deoxyribonucleic acid from its thermal denaturation temperature. J Mol Biol 5, 109-118.

Minnikin, D. E., O’Donnell, A. G., Goodfellow, M., Alderson, G., Athalye, M., Schaal, A. \& Parlett, J. H. (1984). An integrated procedure for the extraction of bacterial isoprenoid quinones and polar lipids. J Microbiol Methods 2, 233-241.

Saitou, N. \& Nei, M. (1987). The neighbor-joining method: a new method for reconstructing phylogenetic trees. Mol Biol Evol 4, 406-425.

Shiba, T. \& Simidu, U. (1982). Erythrobacter longus gen. nov., sp. nov., an aerobic bacterium which contains bacteriochlorophyll $a$. Int J Syst Bacteriol 32, 211-217.
Suzuki, M., Nakagawa, Y., Harayama, S. \& Yamamoto, S. (2001). Phylogenetic analysis and taxonomic study of marine Cytophaga-like bacteria: proposal for Tenacibaculum gen. nov., with Tenacibaculum maritimum comb. nov. and Tenacibaculum ovolyticum comb. nov., and description of Tenacibaculum mesophilum sp. nov. and Tenacibaculum amylolyticum sp. nov. Int J Syst Evol Microbiol 51, 1639-1652.

Swofford, D. L. (1998). Phylogenetic analysis using parsimony (PAUP), version 4. Sunderland, MA: Sinauer Associates.

Tindall, B. J., Sikorski, J., Smibert, R. A. \& Krieg, N. R. (2007). Phenotypic characterization and principles of comparative systematics. In Methods for General and Molecular Microbiology, 3rd edn, pp. 330-393. Edited by C. A. Reddy, T. J. Beveridge, J. A. Breznak, G. A. Marzluf, T. M. Schmidt \& L. R. Snyder. Washington, DC: American Society for Microbiology.

Yoon, J.-H., Kim, H., Kim, I.-G., Kang, K. H. \& Park, Y.-H. (2003). Erythrobacter flavus sp. nov., a slight halophile from the East Sea in Korea. Int J Syst Evol Microbiol 53, 1169-1174.

Yoon, J.-H., Kang, K. H., Oh, T.-K. \& Park, Y.-H. (2004). Erythrobacter aquimaris sp. nov., isolated from sea water of a tidal flat of the Yellow Sea in Korea. Int J Syst Evol Microbiol 54, 1981-1985.

Yoon, J.-H., Oh, T.-K. \& Park, Y.-H. (2005). Erythrobacter seohaensis sp. nov. and Erythrobacter gaetbuli sp. nov., isolated from a tidal flat of the Yellow Sea in Korea. Int J Syst Evol Microbiol 55, 71-75.

Yurkov, V., Stackebrandt, E., Holmes, A., Fuerst, J. A., Hugenholtz, P., Golecki, J., Gad'on, N., Gorlenko, V. M., Kompantseva, E. I. \& Drews, G. (1994). Phylogenetic positions of novel aerobic, bacteriochlorophyll a-containing bacteria and description of Roseococcus thiosulfatophilus gen. nov., sp. nov., Erythromicrobium ramosum gen. nov., sp. nov., and Erythrobacter litoralis sp. nov. Int J Syst Bacteriol 44, 427-434.

ZoBell, C. E. (1946). Marine Microbiology: a Monograph on Hydrobacteriology. Waltham, MA: Chronica Botanica. 